\title{
Arsitektur Bangunan Rumah Tradisional Jawa: Keberadaan Bangunan Tradisional Jawa di Kampung Kauman, Yogyakarta
}

\section{Muhammad Chawari}

Keywords: architecture, urban archaeology, description, javanese traditional houses, typology

\section{How to Cite:}

Chawari, M. (1999). Arsitektur Bangunan Rumah Tradisional Jawa: Keberadaan Bangunan Tradisional Jawa di Kampung Kauman, Yogyakarta. Berkala Arkeologi, 19(1), 128-137. https:/ / doi.org/10.30883/jba.v19i1.798

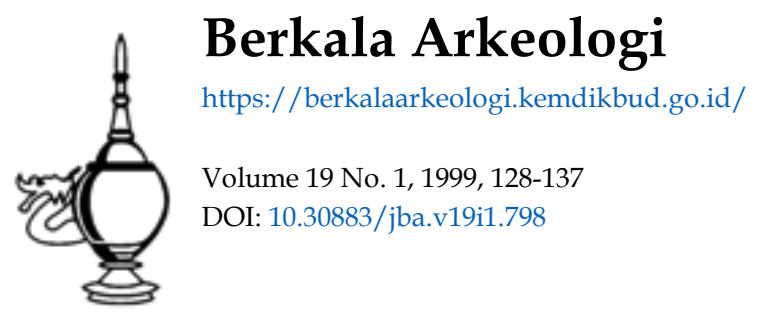

\section{cc) (†) (-)}

This work is licensed under a Creative Commons Attribution-NonCommercial-ShareAlike 4.0 International License. 


\section{ARSITEKTUR BANGUNAN RUMAH TRADISIONAL JAWA \\ Keberadaan Bangunan Tradisional Jawa di Kampung Kauman, Yogyakarta

\author{
Muhammad Chawari \\ (Balai Arkeologi Yogyakarta)
}

\section{Pendahuluan}

Apabila orang berbicara masalah arsitektur Jawa, maka hampir dapat dipastikan yang terlintas di benaknya adalah sebuah rumah dengan atap berbentuk joglo. Pada hal dalam proses perkembangan arsitektur, khususnya di Jawa Tengah saja (sejak abad XIII) telah dapat diklasifikasikan adanya paling tidak lima bentuk dasar. Kelima bentuk tersebut adalah panggang-pe, kampung, tajug atau masjid, limasan, dan joglo atau tikelan (Prijotomo, 1995: 5). Kelima bentuk dasar tersebut kemudian telah berkembang menjadi beraneka jenis dan variasi, bukan hanya berkaitan dengan perbedaan ukurannya saja, melainkan juga dengan situasi dan kondisi daerah setempat yang juga berbeda satu sama lainnya. Dengan demikian meskipun telah ada klasifikasi ragam arsitektur Jawa, penyelesaian dan perkembangan di suatu daerah atau wilayah akan berbeda dengan daerah atau wilayah lain. Tidak ada pembakuan yang berlaku di seluruh Jawa (Budihardjo, 1998: 11). Arsitektur yang demikian merupakan arsitektur yang dipandang secara fisik dalam bentuk keseluruhan jika dilihat dari luar bangunan itu sendiri.

Terlepas dari hal tersebut, arsitektur bangunan rumah tradisional dapat dilihat dalam dua skala, yaitu skala horisontal dan vertikal. Yang dimaksud dengan skala horisontal yaitu membicarakan arsitektur yang berkaitan dengan skala ruang. Maksudnya adalah bangunan rumah ditinjau dalam hal cara pembagian ruangan. Sedangkan yang dimaksud dengan skala vertikal yaitu membicarakan arsitektur bangunan yang berkaitan dengan pembagian bangunan rumah yang terdiri atas lantai dasar atau kaki (umpak dan batur), tubuh atau badan bangunan (tiang dan dinding), dan bagian atas yaitu bagian tertinggi atau puncak bangunan (kepala atau atap). Dalam tulisan ini yang akan dibicarakan berkaitan dengan arsitektur bangunan rumah tradisional Jawa, khususnya yang akan dibahas pada skala horisontal (keruangan).

\section{Bentuk Dasar Rumah Tradisional Jawa}

Rumah bergaya tradisional yang terdapat di Jawa mempunyai bentuk dan kelengkapan yang berbeda dengan bentuk dan kelengkapan rumah-rumah tradisional yang terdapat di daerah-daerah lain di luar Jawa. Secara umum rumah bergaya tradisional Jawa yang mempunyai ciri-ciri sebagai berikut: 


\section{Pendopo}

Pendopo merupakan bangunan yang terletak di bagian depan dari kompleks rumah tradisional Jawa. Pada umumnya bangunan pendopo secara fisik terpisah dengan bangunan induk (dalem). Pada umumnya pendopo merupakan bangunan terbuka tanpa dinding.

\section{Pringgitan}

Secara fisik pringgitan terletak antara pendopo dengan dalem. Dengan demikian pringgitan mempunyai dua bentuk, yaitu:

a. Jika antara pendopo dengan dalem atapnya menjadi satu, maka pringgitan tersebut mempunyai atap. Dengan demikian kedua tidak terpisah dan menyambung.

b. Jika antara pendopo dengan dalem atapnya terpisah, maka pringgitan tersebut tidak mempunyai atap. Dengan demikian kedua terpisah dan tidak menyambung.

\section{Dalem}

Bagian ini (dalem) terletak di tengah-tengah kompleks rumah tradisional Jawa. Bagian ini (dalem) terletak di tengah-tengah dan lantainya terletak paling tinggi dibandingkan dengan lantai dari bagian-bagian rumah lainnya. Secara fisik dalem memakai atap berbentuk joglo, tetapi ada juga yang memakai atap berbentuk limasan. Pada bagian ini terdapat 3 buah ruangan yang terletak paling dalam yang disebut dengan sentong. Ketiga sentong tersebut adalah:

a. Sentong Kiwo yang terletak di sebelah kiri.

b. Sentong Tengah yang terletak di tengah-tengah.

c. Sentong Tengen yang terletak di sebelah kanan.

\section{Gandok}

Gandok merupakan ruangan yang terletak di kiri, kanan, dan belakang dalem. Secara fisik gandok merupakan ruang memanjang yang dilengkapi dengan kamar-kamar. Bangunan ini dapat menjadi satu (menempel) dalem, tetapi dapat juga terpisah.

\section{Gadri}

Gadri merupakan ruangan terbuka yang terletak di belakang sentong.

\section{Keberadaan Rumah Tradisional Jawa Di Kampung Kauman}

Keberadaan Kampung Kauman tidak lepas dari sejarah dan berdirinya Kerajaan Mataram Islam periode terakhir (mulai dinasti Hamengku Buwana). Selain itu, Kauman merupakan salah satu bagian dari birokrasi Kerajaan Mataram tersebut. Beberapa tahun setelah kerajaan ini berdiri, mulai dipikirkan untuk membangun sebuah tempat ibadah (masjid). Akhirnya bangunan masjid besar ini berdiri kira-kira 18 tahun setelah Pangeran Mangkubumi dilantik sebagai sultan dengan gelar Sri 
Sultan Hamengku Buwana I (Chawari, 1989: 94). Setelah masjid ini berdiri, kemudian pihak kerajaan menempatkan seorang penghulu kerajaan. Penghulu ini bertugas untuk mengurusi operasional masjid. Penghulu ini menempati rumahnya yang terletak di sebelah utara masjid. Di kemudian hari tempat ini (rumah dan kantor) terkenal dengan sebutan "pengulon". Dengan demikian pengulon ini berarti rumah dan lingkungannya tempat kedudukan seorang penghulu kraton.

Sampai sekarang rumah penghulu keraton dan lingkungan sekitamya yang dikelilingi dengan tembok ini masih menjadi hak milik keraton kasultanan Yogyakarta. Untuk lebih efektifnya fungsi pengulu tersebut dibuatlah organisasi kepenguluan. Pengulu dan seluruh aparatnya disebut Abdi Dalem Pamethakan (Abdi Dalem Putihan). Tugas dan wewenang pengulu yang erat hubungannya dengan sejarah Kampung Kauman Yogyakarta ialah di bidang kemasjidan. Pejabat dalam organisasi Masjid Besar Kauman Yogyakarta ini terdiri dari orang-orang yang ahli dalam bidang agama Islam. Selanjutnya jenjang kepengurusan Masjid Besar Kauman Yogyakarta yang tertinggi ialah Pengulu, kemudian Ketib, kemudian Modin, kemudian Berjama'ah, dan terakhir Merbot (Darban, 1980: 16-18). Secara lebih jelas struktur kemasjidan adalah sebagai berikut:

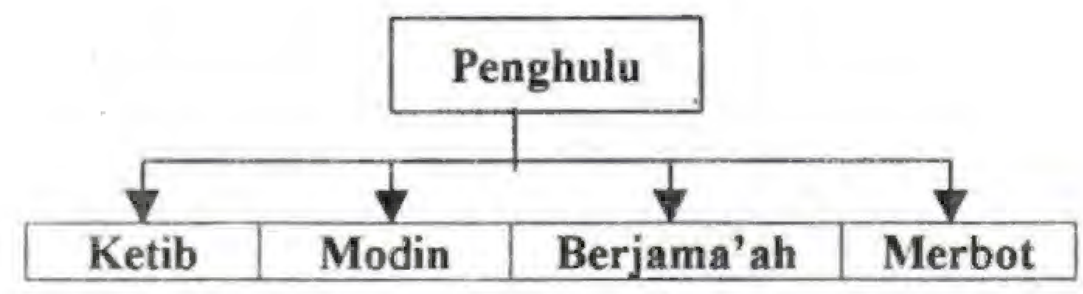

Ketib berjumlah sembilan orag dan dikepalai langsung oleh pengulu. Ketib mempunyai tugas menjadi khotib setiap sholat Jum'at dan tugas mengajar agama dalam pengajian. Kemudian modin berasal dari data mu'adzin yang artinya ialah juru adzan yaitu panggilan untuk orang sholat. Selanjutnya berjama'ah berasal dari kata jama'ah ialah orang yang ditugaskan untuk mendirikan sholat jama'ah dalam rangka memenuhi syarat sholat Jum'at. Terakhir merbot berasal dari kata marbut yang artinya ialah orang yang terikat di dalam masjid. Merbot bertugas sebagai juru bersih masjid dan mengelola fisik masjid.

Selain tugas, wewenang, serta jabatan tersebut, abdi dalem yang mengurusi organisasi kemasjidan (khususnya Masjid Besar Kauman Yogyakarta) mendapatkan fasilitas dari kraton yang berupa tanah gaduhan (kecuali pengulu mendapatkan gaduhan tanah beserta bangunan rumah tinggal). Tanah gaduhan yang diberikan kepada pengulu, ketib, modin, berjama'ah, dan merbot terletak di sekitar masjid. Pengulu mendapat tempat Dalem Pengulon yang terletak di sebelah utara masjid. Dalem Pengulon dikelilingi oleh benteng, dan bentuknya joglo berpendo, serta berfungsi sebagai kantor Kawedanan Pengulon dan sebagai rumah jabatan. Demikian juga para ketib yang 
jumlahnya ada sembilan orang mendapatkan tanah gaduhan di sekitar masjid (Darban, 1980: 19-20). Rumah kedua pejabat ini (pengulu dan ketib) tergolong mewahpada waktu itu. Sebab di samping tanahnya luas, fasilitas bangunannya lengkap (ada pendopo dll), serta dilengkapi dengan hiasan-hiasan.

Berbeda dengan pejabat-pejabat di bawahnya yaitu modin, berjama'ah, dan merbot. Ketiga pejabat ini juga mendapatkan fasilitas dari kraton yang berupa tanah gaduhan. Bangunan rumah ketiga pejabat bawahan ini sangat berbeda dengan kepunyaan pengulu dan ketib, karena lebih sederhana sifatnya. Baik ditinjau dari kelengkapan ruang (pada umumnya tanpa bangunan pendopo), hiasan, dan ukuran luasnya.

Sebetulnya bentuk dan pola dasar rumah tradisional Jawa adalah sama pada semua strata. Yang membedakan adalah kelengkapan dari ruang, hiasan, dan dimensi (ukuran luas). Semakin tinggi stratanya, semakin lengkap ruang-ruangnya, semakin banyak hiasan dan dimensi lebih besar. Demikian juga dengan rumah bergaya tradisional yang terdapat di Kampung Kauman, Yogyakarta mempunyai ciri-ciri yang tidak jauh berbeda dengan rumah tradisinal Jawa pada umumnya. Rumah bergaya tradisional Jawa yang terdapat di Kampung Kauman yang dikatakan lengkap mempunyai ciri-ciri sebagai berikut:
A. Pendopo
B. Peringgitan
C. Dalem/Griyo Ageng
ST : Sentong Tengah
SK : Sentong Kiwo
STn : Sentong Tengen
D. Gadri
E.1. Gandok Tengen
E.2. Gandok Kiwo
E.3. Gandok Mburi (Pawon) (lihat gambar no. 1).

Pada prinsipnya rumah tradisional Jawa terdiri atas tiga bagian terpisah yang membentuk satu kesatuan, masing-masing bagian dengan atap sendiri-sendiri. Ketiga bagian pokok dari rumah Jawa tersebut adalah pendapa, pringgitan (paringgitan atau kampung), dan dalem ageng atau omah buri (Prijotomo, 1992: 40) (gambar no. 2).

Bangunan pendopo merupakan bangunan yang terbuka, baik fungsinya maupun bentuknya secara fisik. Pendopo ini berfungsi sebagai ruang pertemuan, menerima tamu atau kegiatan yang berhubungan dengan masyarakat umum (bukan merupakan tempat tinggal). Kemudian secara fisik bangunan ini tidak memakai dinding baik tembok maupun papan kayu. Hal ini dapat juga ditunjukkan dari keletakannya dalam kompleks rumah tradisioal Jawa, yaitu terletak di paling muka atau paling depan 
sendiri. Sebab tidak ada bangunan lain yang ada di depannya. Bangunan ini memakai atap berbentuk joglo, tetapi dapat juga hadir dengan bentuk limasan ataupun kampung (Prijotomo, 1995: 19).

Pringgitan berasal dari kata dasar ringgit yang mendapat awalan pe dan akhiran an. Kata tersebut mempunyai arti tempat untuk pertunjukan wayang kulit (ringgit). Pertunjukan ini dilakukan apabila pemilik rumah sedang mempunyai hajatan, baik yang berkaitan dengan upacara selamatan ataupun acara ritual lainnya. Selain itu, pringgitan berfungsi sebagai ruang peralihan antara pendopo yang bersifat profan dan umum dengan dalem yang bersifat sakral dan khusus. Dalam perkembangan selanjutnya pringgitan berfungsi untuk menerima tamu yang bersifat tidak formal. Malahan ada yang direlakan menjadi jalan rukunan. Pada beberapa bangunan tradisional kadang-kadang pringgitan ini tidak ada. Jika pringgitan tersebut tidak ada, maka dapat dipastikan bahwa kompleks rumah tradisional tersebut tidak dilengkapi dengan bangunan pendopo yang terdapat di bagian paling depan.

Dalem merupakan pusat (inti) kehidupan keluarga dan tempat penyimpanan harta milik keluarga. Dalem mempunyai kedudukan paling tinggi dan terhormat. Kedudukan ini ditinjau baik secara fisik maupun secara simbolik. Secara fisik ditunjukkan dengan peninggian lantai dalem pada elevasi tertinggi. Sentong merupakan kelengkapan dalem, dan terdiri atas:

a. Sentong Kiwo, yang berfungsi sebagai tempat penyimpanan pusaka dan benda keramat.

b. Sentong Tengah, yang berfungsi untuk pemujaan Dewi Sri (Dewi Kesuburan) dan untuk semedi. Sehingga Sentong Tengah juga disebut Pasren atau Petanen.

c. Sentong Tengen, digunakan untuk tidur orang tua atau mungkin yang dituakan.

Dalam perkembangan selanjutnya, sentong digunakan untuk tidur kepala keluarga atau orang tua atau yang dituakan di dalam keluarga.

Selain ketiga bagian tersebut di atas, masih terdapat beberapa bagian dari bangunan rumah tradisional Jawa. Bagian-bagian tersebut menupakan bagian yang bersifat sebagai pelengkap. Disebut demikian, karena jika bagian-bagian ini tidak ada, tidak akan mempengaruhi keberadaan (eksistensi) bangunan rumah tersebut. Pada umumnya rumah-rumah tradisional Jawa yang terdapat di Kampung Kauman dimiliki oleh orang kebanyakan (rakyat biasa) tidak memakai atau tidak dilengkapi dengan bagian-bagian yang bersifat sebagai pelengkap tersebut (lihat gambar no. 3). Bagianbagian bangunan yang bersifat sebagai pelengkap antara lain meliputi:

Gandok berfungsi untuk tempat tinggal keluarga. Gandok dalam struktur ruang tradisional Jawa merupakan elemen pelengkap. Secara kuantitas gandok dapat dibagi tiga bagian, yaitu: 

a. Gandok tengen (kanan)
b. Gandok kiwo (kiri)
c. Gandok mburi (belakang)

Gandok kanan dan kiri biasanya merupakan kamar-kamar yang digunakan untuk tidur anggota keluarga atau jika ada tamu yang menginap.

Gadri biasanya berfungsi untuk duduk-duduk santai keluarga dan sering digunakan untuk ruang makan.

Bagian-bagian seperti tersebut di atas merupakan bagian-bagian yang secara arsitektural dapat dikenali keberadaannya. Selanjutnya ada hal lain yang tidak termasuk dalam arsitektur yang berkaitan dengan skala ruang, yaitu arah hadap. Pada umumnya rumah-rumah yang ada mempunyai arah dua (2) alternatip arah hadap yaitu utara dan selatan. Arah utara pada umumnya dianggap sebagai arah formal untuk yang bukan pribadi, dan arah selatan untuk yang bersifat pribadi. Di beberapa daerah, gunung dilihat sebagai lambang alam atas dan laut sebagai lambang alam bawah. Arah matahari terbit dan terbenam memiliki arti yang lebih umum, yaitu arah timur untuk kepentingan jasmaniah atau dunia kerja manusia masa kini, sedangkan arah barat untuk kepentingan rokhaniah atau dunia kekuasaan leluhur masa lampau (Budihardjo, 1998: 14-15).

Selanjutnya arah hadap rumah pada umumnya berkaitan dengan keyakinan bahwa di utara terdapat Gunung Merapi dan di sebelah selatan terdapat Lautan Selatan. Di daerah Yogyakarta kedua arah tersebut (utara dan selatan) memiliki arti tersendiri. Arah selatan memiliki arti sehubungan dengan kepercayaan atas adanya kerajaan Nyi Ratu Roro Kidul. Atas dasar itulah rumah yang menghadap ke selatan secara tidak langsung memberikan penghormatan kepada Nyi Ratu Roro Kidul tersebut (Budihardjo, 1998: 14). Sedangkan arah utara berhubungan dengan penjaga Gunung Merapi. Oleh karena itulah di daerah Parangtritis dan Gunung Merapi setiap tahun selalu diadakan upacara labuhan yang dilakukan oleh pihak kraton Kasultanan Yogyakarta.

Berikutnya di Kampung Kauman ada yang dinamakan rukunan. Rukunan merupakan jalan kecil yang melewati persil tanah seseorang atau beberapa orang. Rukunan ini dengan kesepakatan bersama direlakan untuk dilewati dan dimanfaatkan untuk aksesibilitas umum. Biasanya rukunan berfungsi untuk memperpendek jarak ke jalan yang lebih besar. Dalam beberapa kasus rukunan ini sebetulnya merupakan pringgitan atau salah satu bagian dari bangunan rumah salah satu keluarga, tetapi karena perkembangan jaman akhirnya direlakan untuk jalan umum. 


\section{Kesimpulan}

Berdasarkan hal-hal yang telah diuraikan sebelumnya terdapat beberapa kesimpulan.

1. Pada dasarnya rumah tradisional Jawa yang paling sederhana memiliki tiga komponen utama, yaitu pendapa, pringgitan, dan dalem.

2. Rumah tradisional Jawa yang terdapat di Kampung Kauman Yogyakarta ada dua kelompok, yaitu kelompok yang sederhana dan kelompok yang lengkap.

3. Rumah tradisional Jawa yang terdapat di Kampung Kauman Yogyakarta yang tergolong sederhana pada umumnya dimiliki oleh orang kebanyakan atau rakyat biasa. Sedangkan yang tergolong lengkap dimiliki oleh pejabat keraton yaitu pengulu dan ketib.

\section{KEPUSTAKAAN}

Budihardjo, Eko, Prof, Ir, M.Sc, 1998. Percikan Masalah Arsitektur, Perumahan, Perkotaan. Yogyakarta: Gadjah Mada University Press, cetakan keempat.

Chawari, Muhammad, 1989. Pasang Surut Perkembangan Pembangunan Masjid Besar Kauman Yogyakarta, Studi Berdasarkan Sumber Prasasti. Yogyakarta: Skripsi Sarjana pada Jurusan Arkeologi, Fakultas Sastra, Universitas Gadjah Mada.

Darban, Ahmad Adaby, 1980. Sejarah Kauman Yogyakarta Tahun 1900-1950, Suatu Studi Terhadap Perubahan Sosial. Yogyakarta: Skripsi Sarjana pada Jurusan Sejarah, Fakultas Sastra, Universtas Gadjah Mada.

Prijotomo, Josef, 1992. Ideas and Forms of Javanese Archetecture. Yogyakarta: Gadjah Mada University Press, cetakan ketiga.

1995. Petungan: Sistem Ukuran Dalam Arsitektur Jawa. Yogyakarta: Gadjah Mada University Press.

Wibowo, H.J. dkk, 1986/1987. Arsitektur Tradisional Daerah Istimewa Yogyakarta. Yogyakarta: Departemen Pendidikan dan Kebudayaan, Proyek Inventarisasi dan Dokumentasi Kebudayaan Daerah. 


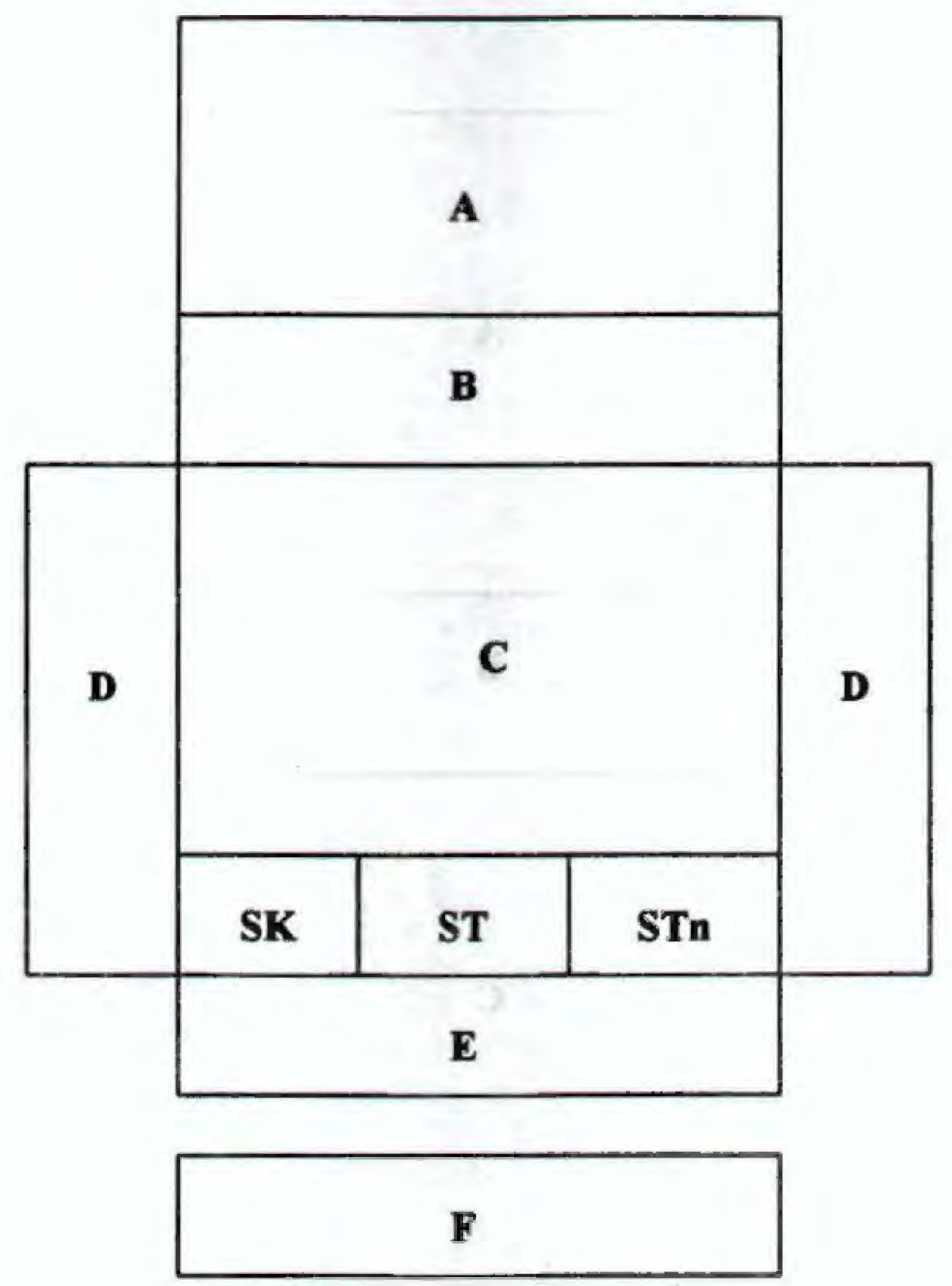
A. Pendapa
B. Pringgitan
C. Dalem
SK: Sentong Kiwo (kiri)
ST: Sentong Tengah
STn: Sentong Tengen (kanan)
D. Gandok
E. Gadri
F. Pawon (dapur)

Gambar 1. Denah bangunan rumah tradisional Jawa lengkap yang terdapat di Kampung Kauman Yogyakarta 


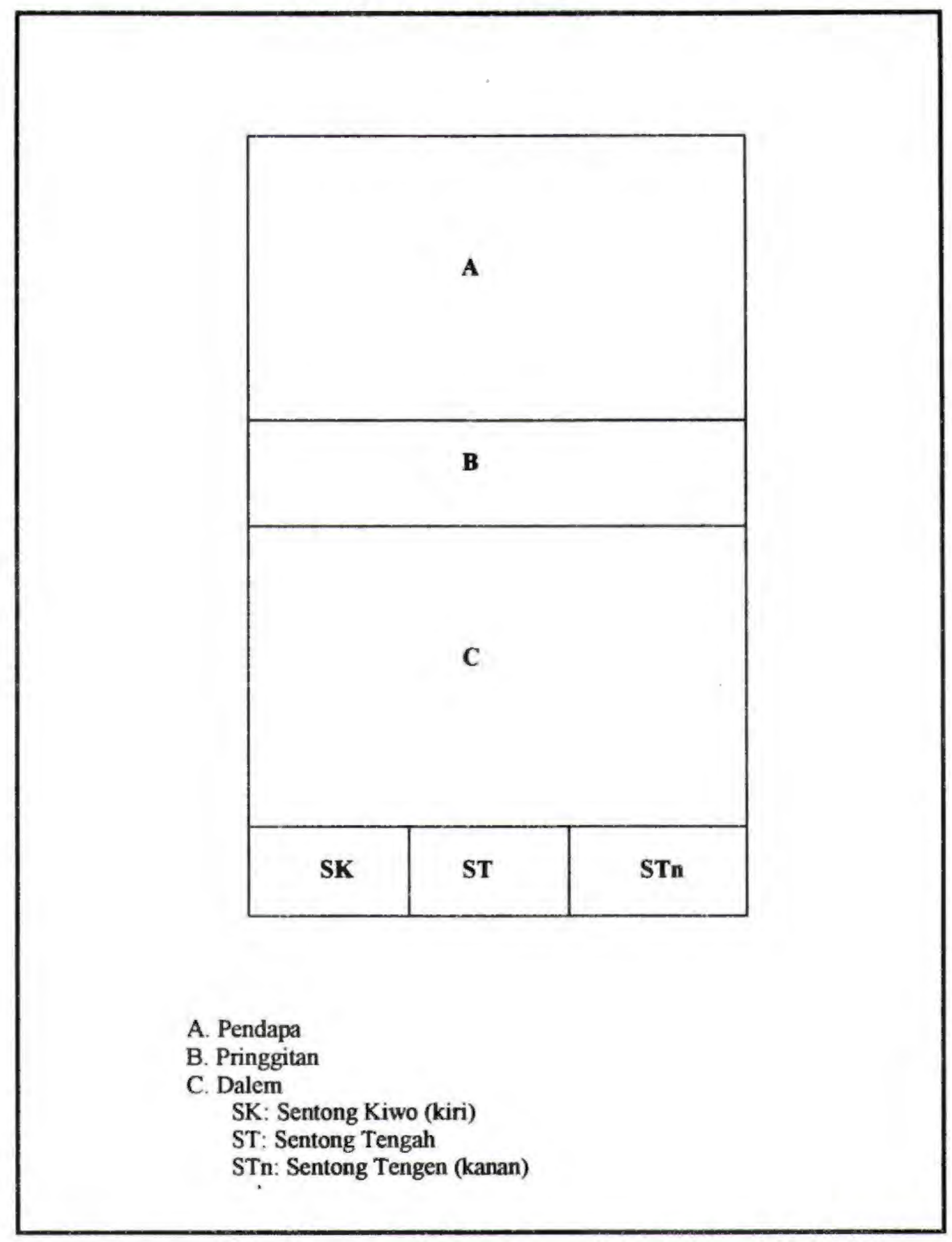

Gambar 2. Denah bangunan rumah tradisional Jawa yang sederhana. 


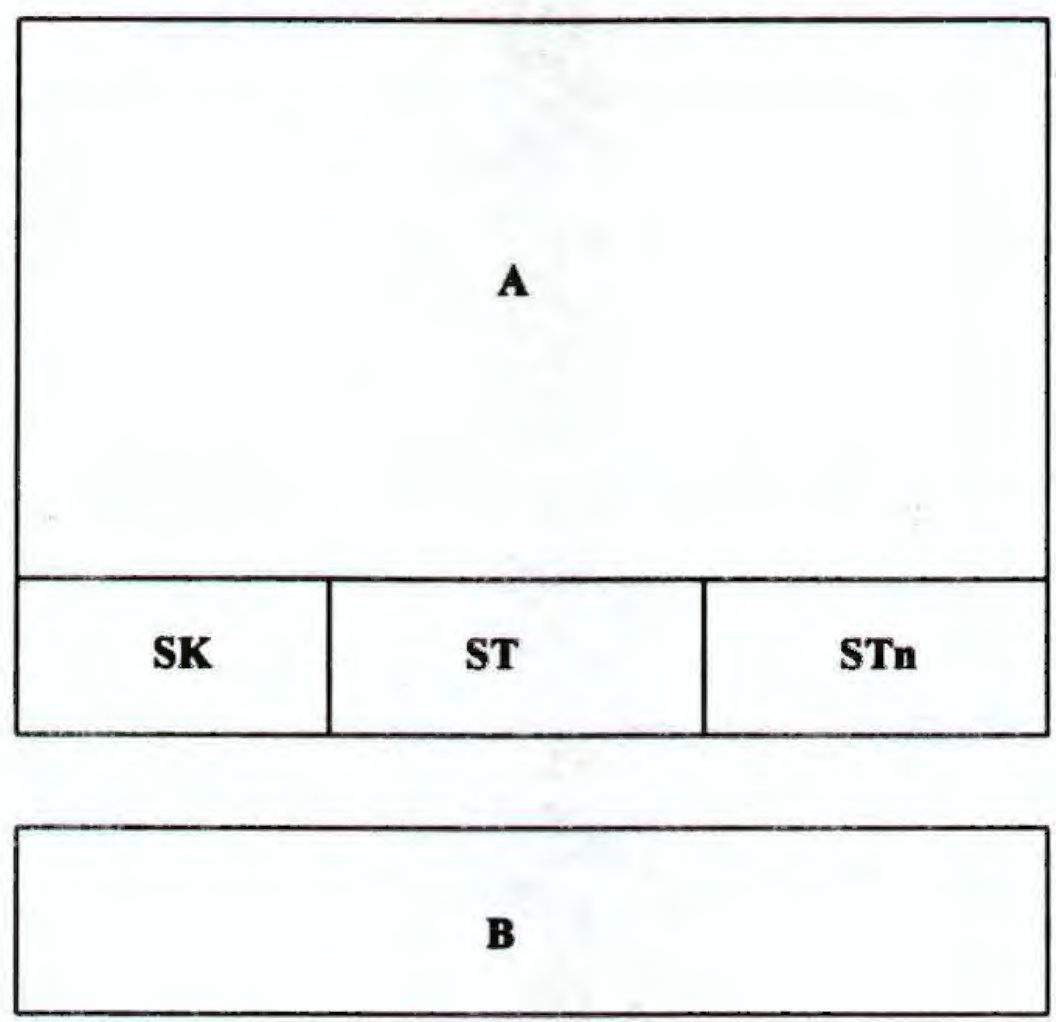

A. Dalem

SK: Sentong Kiwo (kiri)

ST: Sentong Tengah

STn: Sentong Tengen

(kanan)

B. Pawon (dapur)

Gambar 3. Denah bangunan rumah tradisional Jawa sederhana yang terdapat di Kampung Kauman Yogyakarta. 